\title{
Evaluation of different insecticides against major insect pests of rice in Punjab
}

\author{
GURMAIL SINGH SANDHU* AND N.S. DHALIWAL
}

Krishi Vigyan Kendra, SRI MUKTSAR SAHIB (PUNJAB) INDIA

\section{ARITCLE INFO \\ Received : 21.01 .2016 \\ Revised : 26.02.2016 \\ Accepted : 07.03.2016}

\section{KEY WORDS :}

Cartap hydrochloride, Flubendiamide, Fipronil, leaf folder, Stem borer
*Corresponding author:

Email: gurmailent@pau.edu

\begin{abstract}
Field experiments were conducted at Krishi Vigyan Kendra, Sri Muktsar Sahib, Punjab, to find effectiveness of different insecticides against stem borer and leaf folder in rice and basmati rice. During Kharif 2014, Fame 480 SC (flubendiamide $39.35 \%$ ) @ $50 \mathrm{ml} / \mathrm{ha}$, Dursban (chlorpyriphos 20\% EC) @ 2500 ml/ha, Marktriazo (triazophos 40\% EC) @ 875 $\mathrm{ml} / \mathrm{ha}$ and Sutathion (triazophos $40 \%$ EC) @ $875 \mathrm{ml} /$ ha were tested along with untreated control in rice. All the insecticidal treatments were significantly superior to untreated control. Fame 480 SC @ 50 ml/ha was found most promising with minimum dead heart, white ear and leaf folder incidence. During, Kharif 2015, three different brands of fipronil 0.3 G (Mifpro-G, Mahveer GR, Regent) @ 15kg/ha, two brands of cartap hydrochloride 4 per cent G (Miftap, Nidan) @ $25 \mathrm{~kg} / \mathrm{ha}$ were tested along with flubendiamide (Fame $480 \mathrm{SC}$ ) @ $50 \mathrm{ml} / \mathrm{ha}$ in basmati rice. The data on dead heart, white ear, leaf folder incidence, grain yield showed that all the insecticides effectively control the stem borer on basmati rice, but Fame 480 SC, Nidan and Miftap were comparatively more effective against leaf folder. Considering the efficacy data and very low dose (ha ${ }^{1}$ ), Fame $480 \mathrm{SC}$ proved to be better option for management of two major pests of rice.
\end{abstract}

How to view point the article : Sandhu, Gurmail Singh and Dhaliwal, N.S. (2016). Evaluation of different insecticides against major insect pests of rice in Punjab. Internat. J. Plant Protec., 9(1) : 187-192. 